\title{
BUSINESS IN MODERN CONDITIONS OF MANAGEMENT
}

\author{
Svitlana Sliusar ${ }^{1}$
}

\begin{abstract}
The paper's purpose is to provide recommendations for carrying out theoretical bases of existence, the analysis of the current state and the prospects of development of business in Ukraine. Methodology. During the writing of the article, the following research methods were used: the search for available methodological and scientific literature, comparison, clarification of causal relationships, systematization, analysis of documentation and results of researchers' work on the problem of the conducted research and expert evaluation. Results. Business development is very difficult and multidimensional, and the influence of many factors on small and medium business entities and is ambiguous and, therefore, demands further complex evidence-based analysis. It concerns such aspects of a research as: a research of positive processes in the conditions of making shifts in infrastructure, which cause the accelerated development of small and medium business entities and its social and economic consequences; deeper determination of regularities of formation and development of small business as one of structure-forming factors of market economy of Ukraine; improvement of the organizational and economic mechanism of the state support of small and medium business in Ukraine and also in its certain regions and spheres of action. Practical implications. It is noticed, there are positive shifts in the course of improvement of conditions of business because of the reduction of a number of permitting documents and licensing types, simplification of procedures for obtaining licenses and permissions, reduction of the controlling pressure upon business, improvement of the sphere of providing administrative services, strengthening of responsibility for violation of the legislation in the sphere of economic activity. Value/originality. In the article, the latest statistical data are used according to the analysis of the current state of functioning of business in Ukraine, problems and the directions of development of small and medium business in Ukraine are selected.
\end{abstract}

Key words: entrepreneurship, small business, medium business, economy, gross domestic product, development.

JEL Classification: E22, L11, M11, O20

\section{Introduction}

At the present stage of development of Ukraine, support of formation and development of business is one of the defining priorities of public policy from first years of economic reforms. Today Ukraine is one of those countries having the difficult system of taxation; therefore, some businessmen pass into the shadow sector of the economy. But in order to prevent this phenomenon of a hidden economy, it is necessary to reduce the quantity of taxes, to simplify the process of registration of firm and the reporting, and also to improve the Tax Code of Ukraine, adapting it for modern conditions of management and international experience.

The significant role of small and medium-sized enterprises in providing the competitive environment, the flexibility of the national economy, employment and the income of the population received great value at all levels and found the manifestation in the implementation of special measures of public policy for support of business development in Ukraine. Therefore, the creation of a model of economic development, which would provide the greatest possible distribution of positive tendencies of economic dynamics on all components of the economic system, remains among the main tasks of the state economic strategy so far. Respectively, the relevance of business development is caused, in particular, by the fact that today small and medium-sized enterprises create the main part of the gross domestic product in the countries with the developed market economy, among which Ukraine; therefore, this sector requires the greatest attention from researchers and reformers.

\section{Research and literature analysis}

With the development of market economy, the role of business amplifies, and it involves domestic researchers in whose works these or those aspects of the business are considered. The modern theory of business is the result of the scientific thought of many scientists. This problem was studied by R. Kantilyon, A. Marshall,

Corresponding author:

${ }^{1}$ Pereiaslav-Khmelnytskyi Hryhorii Skovoroda State Pedagogical University, Ukraine.

E-mail: devko89@ukr.net 
S. Simsodi, J. Schumpeter, etc. A number of scientific works of such scientists as S. Varnaly, G. Vasin, L. Vorotin, M. Nizhny, A. Danilenko, M. Kozoriz, S. Mocherny, V. Pavlov, and others are in recent years published. According to scientists, illumination of tools for own business, marketing orientation of entrepreneurial activity, business planning and use of the principles of management was essential. They sought to create, the researches, future experts of economic specialties have systems of knowledge directed to optimization of management, activation of entrepreneurial activity in Ukraine, the transformation of business into the independent leading sector of the economy in the conditions of sustainable development of the country. Their doctrine captured all range of application of the modern theory of business: the analysis and identification of enterprise strategy and the direction of its realization, marketing orientation of entrepreneurial activity, and means of introduction of management in its organization. Scientists considered various aspects of business development in Ukraine, a role and value of this sector in the industrial states and developing states, in particular, with a transitional economy. At the same time, the lack of the deep analysis and rather clear understanding of the place and a role of business in modern model of market economy do not allow formulating accurately the concept of the mechanism of support of business development in Ukraine.

\section{Statement of a problem}

In Ukraine, business as the independent social and economic phenomenon develops in difficult conditions and faces various problems. High level of corruption, excessive bureaucracy and control from public authorities are characteristic of Ukraine, a large number of unscheduled inspections. In EU countries, there is created an extensive network of the organizations, which are engaged in regulation and support of business development, but among public authorities, responsibilities for business development are distributed between several ministries or between special departments (Bekh, 2012).

It is possible to say that small and medium business includes more than $90 \%$ of the companies registered in Ukraine, however, a real contribution of these enterprises to GDP - about 11\% (Derenko, 2014). Small business does not play that significant role in the national economy as in developed countries where it provides $60-70 \%$ of GDP. Therefore, special attention should be paid to the creation of effective and efficient mechanisms of support and protection of small business from the state and to stimulate its development. For this purpose, it is necessary to reduce the tax load and to grant soft loans.

One of the most common forms of stimulation of development of the sector of small business in developed countries of Europe is the creation of preferences for them in the taxation by the introduction of special tax rules (France) or application of the general rules on separate privileges for small enterprises (Great Britain). Though in Ukraine, the simplified tax system also works but, for the improvement of small business development, it is necessary to consider the international practice of application of the simplified (special) tax treatments (Klochko et al., 2016).

With the acceptance in 2012 of the Law of Ukraine "On Development and State Support of Small and Medium Enterprises in Ukraine" changes are made to the Commercial Code of Ukraine regarding the definition of concepts of large, small, and medium business entities, brought into accord with the EU classification. In 2012, the share of small and medium business entities made $99.96 \%$ of the total of economic entities that in general conform to the European standards.

\section{Structure of economic entities according to the current legislation of Ukraine}

According to State Statistics Service of Ukraine as of 01.01.2017 in Ukraine, there were 1600127 economic entities from which 698 entities of a large business, 20550 entities of medium business and 1578879 small business entities. During 2013-2017, reduction of a number of small and medium business entities was observed. In the structure of economic entities, the share of medium business entities increased from $1.24 \%$ of a total of economic entities in 2013 to $1.29 \%$ in 2017 due to the reduction of a number of small business entities (State Statistics Service of Ukraine).

According to the current legislation of Ukraine, legal entities and individuals can be participants of the economic relations. For the beginning of 2017 in Ukraine, economic activity was carried out by 364935 legal entities from which 20189 - mediumsized enterprises and 344048 - small enterprises, and 1235192 - individual entrepreneurs. The tendency to proliferation was characteristic only of the individual entrepreneurs who are carrying out the activity in the sphere of medium business.

In the structure of domestic business by the size of the enterprises as of 01.01.2017, the share of small enterprises was $94.3 \%$, medium $-5.5 \%$ and large $-0.2 \%$ (Figure 1).

As well as in previous years, the overwhelming number of medium-sized and small enterprises of Ukraine was concentrated in the Dnipropetrovsk, Kyiv, Lviv, Odesa, Kharkiv regions and in the city of Kyiv. The smallest quantitative indices of medium-sized and small enterprises are shown by the Volyn, Zakarpattia, IvanoFrankivsk, Rivne, Ternopil, Chernivtsi regions.

By results of 2016, quantitative indices of mediumsized and small enterprises per 10000 population of Ukraine, in comparison with 2015, decreased from 


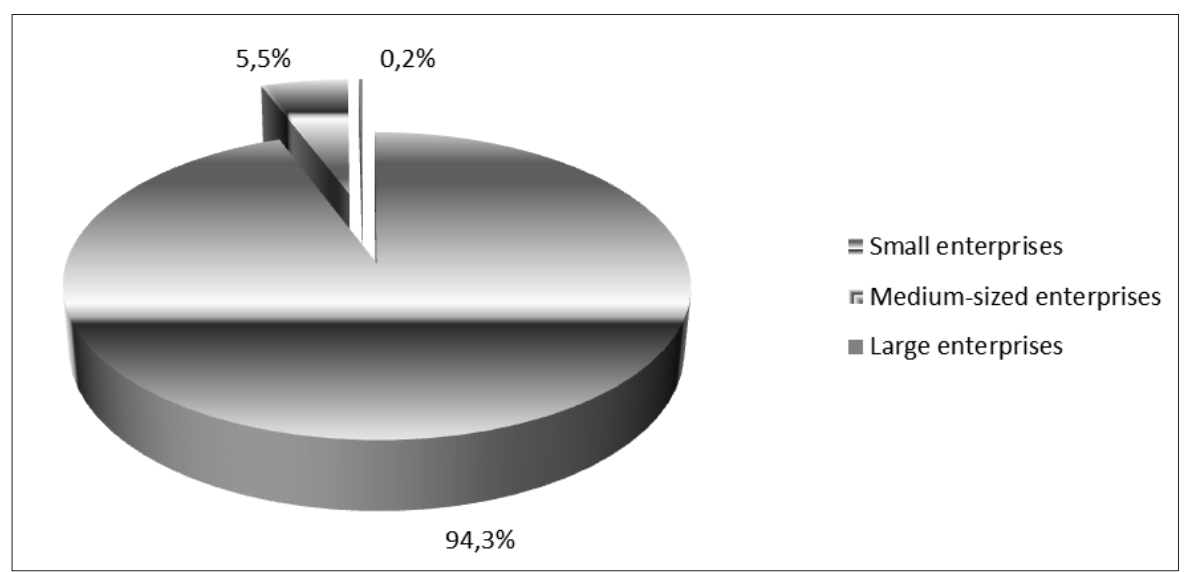

Figure 1. The number of enterprises by their size in $\%$ to a total of the enterprises as of 01.01.2017

Source: Statistical information of the State Statistics Service of Ukraine, built by the author using the MS Excel package

5 to 4 units for medium-sized enterprise and from 77 to 76 units for small enterprises per 10000 people of an actual population of Ukraine.

In a regional section, the best indicators of a number of small enterprises per 10000 people of the population of Ukraine are in the city of Kyiv, and Odesa, Kyiv, and
Kharkiv regions. The lowest indicators of a number of small enterprises per 10000 population of Ukraine are in the Ternopil, Sumy, Zakarpattia, Chernivtsi, and Rivne regions (Figure 2).

As of 01.01.2017, the total number of individual entrepreneurs per 10000 population of Ukraine is

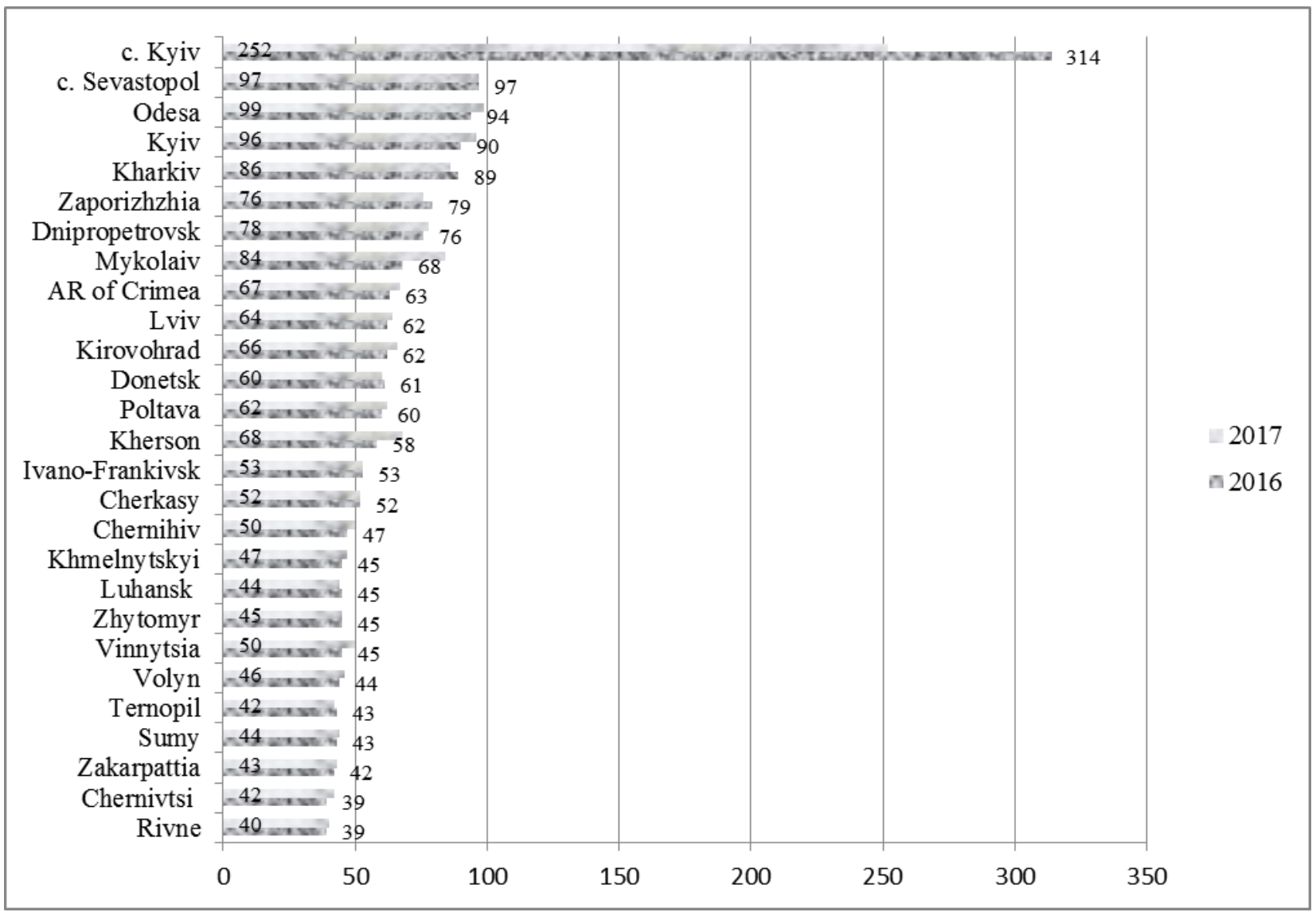

Figure 2. The number of small enterprises per 10000 population of Ukraine by regions (units)

Source: Statistical information of the State Statistics Service of Ukraine, built by the author using the MS Excel package 


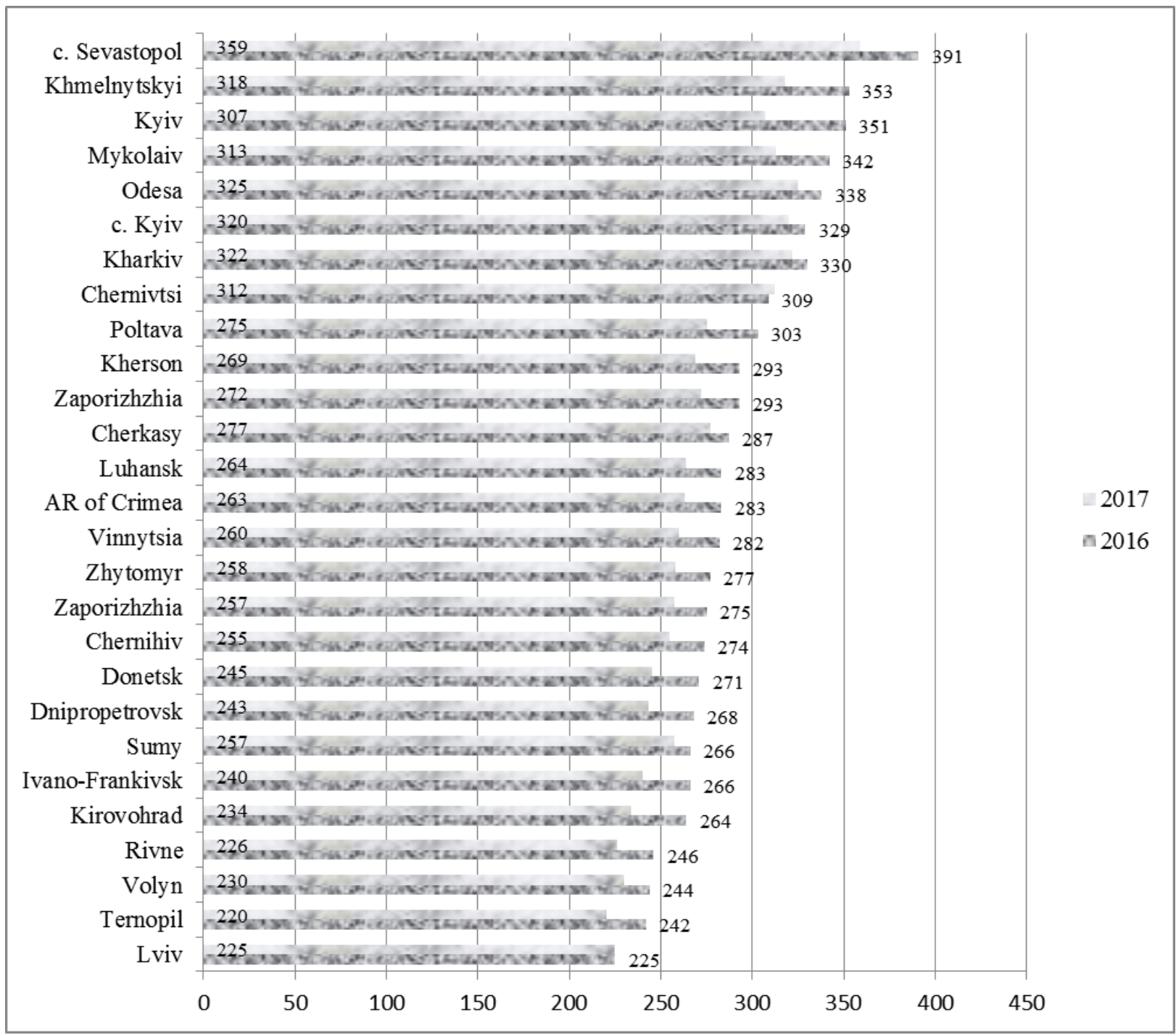

Figure 3. The number of individual entrepreneurs per 10000 people of the available population in Ukraine by regions (units)

Source: Statistical information of the State Statistics Service of Ukraine, built by the author using the MS Excel package

271 units, which is $6.6 \%$ less than for the reporting period of the last year. The best this indicator is in the Khmelnytskyi, Kyiv, Mykolaiv, and Odesa regions, and the worst - in the Kirovohrad, Rivne, Volyn, Ternopil, and Lviv regions (Figure 3) (State Statistics Service of Ukraine).

By the end of 2017, 7,5 million people were engaged in the sector of small and medium business who make $40 \%$ of an occupied population of working-age. In comparison with 2016, the number of busy workers at small and medium business entities decreased by $3 \%$. At the same time, 2017 was characterized by a delay in the rate of reduction of a number of employed in this sphere as in 2016 this indicator decreased by $8 \%$, in comparison with 2015. Delay happened due to a significant increase (more than twice) in the number of those engaged in individual entrepreneurship carrying out the activity in the sphere of medium business. The number of individual entrepreneurs taking into account hired workers as of 01.01.2017 made 2,3 million people (State Statistics Service of Ukraine).
In the structure of employment of the population at enterprises for 2015-2017, there were minor changes in favour of large enterprises at the expense of mediumsized enterprises. So, in 2015 at large enterprises, 30\% of an occupied population worked at the enterprises and at medium-sized enterprises $-43 \%$ of an occupied population at the enterprises, and in 2016 - 32\% and $41 \%$ of an occupied population at the enterprises respectively.

In the sphere of small and medium business by results of 2016, 6,1 million people from whom 51\% of hired workers worked at medium-sized enterprises, 3\% - at small enterprises, and $17 \%$ of workers were employed by individual entrepreneurs.

According to State Statistics Service of Ukraine as of 01.01.2017, the total amount of the sold products (goods, services) by business entities was 4460,0 billion hryvnias, that is $6 \%$ more in comparison with 2015. 


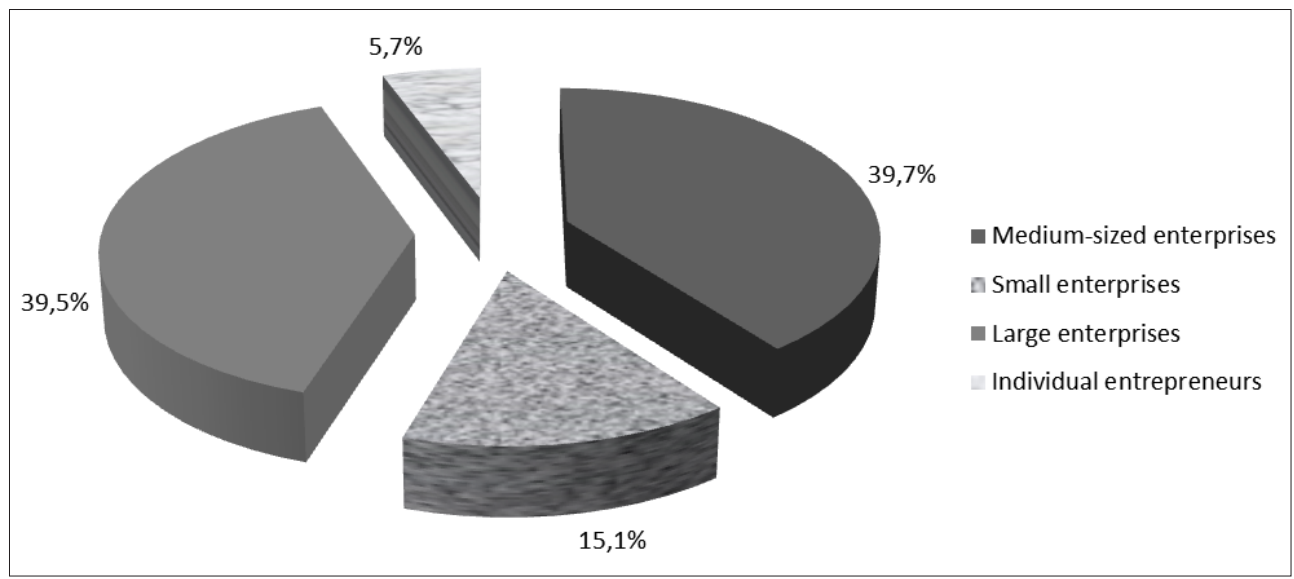

Figure 4. The share of enterprises in the volume of the sold products for 2017

Source: Statistical information of the State Statistics Service of Ukraine, built by the author using the MS Excel package

In 2016, the volume of the sold products (goods, services) of small and medium business entities grew by $11.2 \%$ in comparison with the previous year and was 2698,7 billion hryvnias. At the same time, the gain was observed both for small and for medium business.

Small and medium business entities for 2016 realized $60.5 \%$ of the total amount of the products (goods, services) sold in Ukraine, from them $39.7 \%$ are realized by medium-sized enterprises, $15.1 \%$ - small enterprises and 5.7\% - individual entrepreneurs (Figure 4) (State Statistics Service of Ukraine).
In distribution by types of economic activity, trade and service trade, which share in the total amount of the sold products (goods, services) is totally more than $60 \%$ remain priority spheres of action of small and medium business entities. Much less are industry indicators (20.3\%), agricultural industry (5.5\%), and construction (5.4\%) (Figure 5) (State Statistics Service of Ukraine).

In 2016, 111382,9 million Ukrainian hryvnias of capital investments from which 75247,4 million hryvnias-medium-sizedenterprisesand 36135,5 million hryvnias - small enterprises, were attracted with small and medium-sized enterprises.

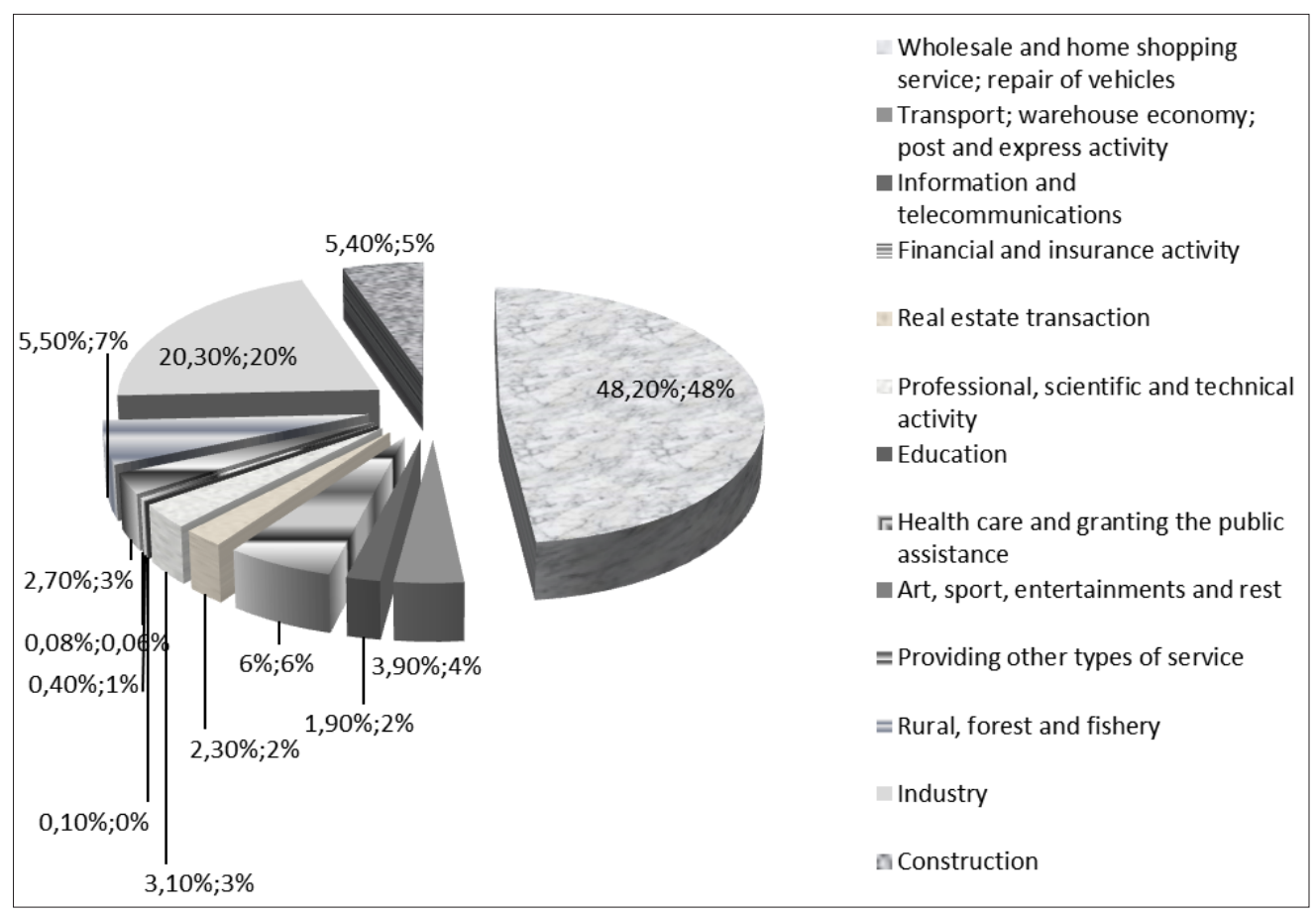

Figure 5. Specific weight of small and medium business entities in volumes of product sales by types of economic activity for 2016

Source: Statistical information of the State Statistics Service of Ukraine, built by the author using the MS Excel package 
In comparison with 2015 , the volume of the involved capital investments increased by 11 193,2 million hryvnias. In 2016, there were changes in the structure of the attraction of capital investments due to the increase in investments into large enterprises. So, $50 \%$ of capital investments were directed to large enterprises, 34\% - to medium-sized enterprises and $16 \%$ - to small enterprises.

\section{Financial result before the taxation of economic entities}

Own means of the enterprises and organizations and also the credits of banks and other loans still remain the main source of financing of capital investments. Such structure of sources of financing of capital investments, namely domination in it of payments for the account of own means of the enterprises, puts into dependence enterprises' development and their investment activity on their profitability (Pikhnyak).

As of 01.01.2017 the financial result before the taxation of the enterprises which got profit was 248035,9 million hryvnias. For medium-sized enterprises, this indicator was 111313,2 million hryvnias that as a percentage to a total of the enterprises makes $66.2 \%$, and for small enterprises - 39794,1 million hryvnias that as a percentage to a total of the enterprises makes $64.4 \%$.

Before the taxation, the small and medium-sized enterprises which are carrying out the activity in the following spheres had the greatest value of financial result: rural, forest and fishery; wholesale and home shopping service; industry; operations with a fast estate.

Slowly fiscal charges from small and medium business entities in budgets of all levels grow. So, 289 319,0 million hryvnias came to the Consolidated Budget for 2016 from small and medium business entities that is $8.6 \%$ more than for the reporting period of the last year [9]. Dynamics of changes of a position of Ukraine in the rating of business conditions are given for 2013-2017 (see Figure 6) (Economy under firing).

Dynamics of changes in Ukraine's position in the rating of business conditions are given in Table 1.

Following the results of the World Bank's Doing Business-2016 rating, Ukraine rose by the 28th position in comparison with last year's rating and took the 112th place. Ukraine is recognized as the country, which achieved the best results on the improvement of the regulatory environment of all countries of the world in 2013-2017.

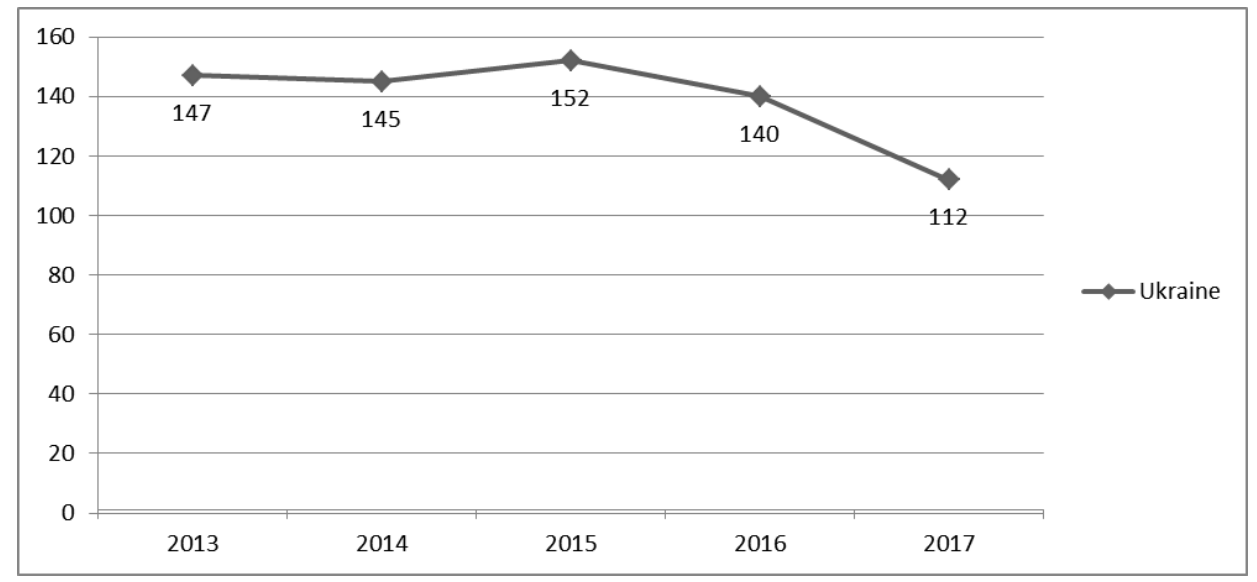

Figure 6. Dynamics of changes in Ukraine's position in the rating of business conditions for 2013-2017 (Economy under firing)

Table 1

Dynamics of changes in Ukraine's position in the rating of business conditions

\begin{tabular}{|l|c|c|c|}
\hline \multicolumn{1}{|c|}{ Categories } & Doing Business-2015 & \multicolumn{2}{c|}{ Doing Business-2016 } \\
\hline Place of rating & 140 & \multicolumn{2}{c|}{112} \\
\hline Registration of the enterprises & 50 & +3 & 47 \\
\hline Obtaining construction licenses & 186 & -2 & 41 \\
\hline Connection to power supply & 170 & +61 & 97 \\
\hline Registration of property & 158 & +11 & 13 \\
\hline Crediting & 24 & -1 & 128 \\
\hline Protection of investors & 127 & +4 & 164 \\
\hline Taxation & 168 & $=$ & 148 \\
\hline International trade & 148 & $=$ & 45 \\
\hline Efficiency of judicial system at the decision of commercial disputes & 45 & -5 & 162 \\
\hline Solution of insolvency (liquidation of the enterprises) & 157 & & \\
\hline
\end{tabular}




\section{The results of the study}

The World Bank noted carrying out reforms in Ukraine in eight directions from ten, investigates the Rating of business conditions. Moreover, Ukraine headed the list from ten states, which achieved the greatest progress in the improvement of conditions for business. Ukraine made the greatest progress by such criteria as obtaining permissions in construction - 41 steps against 186 in the Rating 2015 , registration of property - 97 against 158 , access to crediting - 13 against 24 (State Statistics Service of Ukraine).

About $65 \%$ of the general indicator in raising the country in the rating of business conditions was made by the construction branch. Respectively, the introduction of the Law of Ukraine "On Regulation of Town-Planning Activity” allowed simplifying considerably permitting procedures in construction:

- the number of the documents necessary to start construction is reduced;

- the order of acceptance of the constructed objects in operation and reduced term is simplified;

- date of receipt of documents is significantly reduced;

- registration of the new real estate unit is improved, the number of necessary procedures and their terms is reduced.

The number of procedures decreased from 20 to 10. Time of obtaining permitting documents decreased more than by 5 times. The cost of paperwork decreased twice (Klochko, 2017). Improvement of a position of Ukraine on category "registration of property" happened due to the reduction of registration procedures from 10 to 8 . The process of registration of property was reduced by 25 days (from 70 to 45 days). The cost of expenses for the execution of all necessary documents and passing procedures decreased almost twice. In the last report, specialists of the World Bank placed emphasis on category "taxation" - the 164th place (+ 4 positions).

Reduction of documentation, reduction of the reporting, acceleration of formalities, development of electronic services - all this allows the payer to save time and, respectively, creates operating business conditions in Ukraine comfortable. So, time expenditure on the observance of requirements of the tax legislation was reduced by 101 hours (last year the taxpayer spent for tax procedures 491 hours a year, for June 1 of 2017 - 390 hours). Reduction of time became possible due to the simplification of declarations for payment of the VAT and USC and also improvement of the electronic reporting system. By research estimates, in a year the tax rate in Ukraine decreased from $55.4 \%$ to $54.9 \%$, the number of payments remained at the level of last year -28 (Zhalila, 2016).
Also, the improvement of customs administration after the introduction of the new Customs Code is noted. Ukraine made international trade simpler due to faster execution of customs declarations and reduction of a number of physical surveys of goods. In particular, the time necessary for the import of goods to Ukraine is reduced from 33 to 28 days, for export - from 30 to 29 days. Registration of export requires 6 documents, import -8 documents (Zhalila, 2016).

\section{Conclusions}

Positive shifts in process of improvement of business conditions - all this contributed to the achievement of notable progressing in different spheres received a positive estimate from the organizations and experts. In particular, according to the World Bank's Ease of Doing Business Rating for Ukraine, in 2016 Ukraine took the 112th place, improved its position by 28 points. However, changes which happened did not provide an increase in a number of small business entities yet, the number of the individual entrepreneurs who are carrying out the activity in the sphere of medium business only slightly increased. The analysis of domestic business structure, both across Ukraine in general and its regions, shows that it remains invariable in recent years and the lion's share is made by small enterprises (94.3\%). Own means (59.2\%) remain the main source of investment for economic entities, and the budgetary and credit mechanisms of business support are not effective. Thus, development of investment activity of business entities depends on their profitability.

Overcoming the factors constraining the development of business is possible by the implementation of the new state business development strategy in Ukraine, in particular, within the Nationwide Small and Medium Business Development Program for 2024, which is directed to creating favourable conditions of activity of small enterprises and supports its development on the basis of the introduction of innovative technologies, instruments of cooperation of small, medium, and large business entities.

It is also necessary to continue work in the sphere of deregulation in the direction of facilitation of the creation and termination of entrepreneurial activity by the establishment of the principle of implementation without application of seals, the introduction of amendments to acts concerning the improvement of business liquidation procedures; improvement of licensing procedures and obtaining permits. Also, improvement of the legislation concerning the state supervision (control) in the sphere of economic activity, in particular, increase in the level of responsibility of public officials of appropriate authorities is relevant. 


\section{References:}

Bekh, N. (2012). Osoblyvosti rozvytku i funktsionuvannya maloho i serednoho biznesu v Ukrayini ta sviti [Features of development and functioning of small and medium business in Ukraine and World]. Halytskyy ekonomichnyy visnyk, 1, 16-20. (in Ukrainian)

Derenko, O. A. (2014). Mizhnarodnyy dosvid derzhavnoho rehulyuvannya ta pidtrymky pidpryyemnytstva [International experience of state regulation and Business]. Biznesinform, 5, 95-9.7 (in Ukrainian)

Ekonomika pid obstrilom. Yak viyna na Skhodi vplyvaye na narodne hospodarstvo [Economy under firing. As war in the east influences the national economy]. State Statistical Service of Ukraine. Retrieved from: http://tyzhden.ua/ Economics/115190 (in Ukrainian)

Pikhnyak, T. A. Svitovyy dosvid derzhavnoho upravlinnya rozvytkom maloho pidpryyemnytstva i mozhlyvosti yoho adaptatsiyi v Ukrainy [International experience of public administration by development of small business and a possibility of its adaptation in Ukraine]. Retrieved from: http://intkonf.org/pihnyak-ta-svitoviy-dosvid-derzhavnogoupravlinnya-rozvitkom-malogo-pidpriemnitstva-i-mozhlivosti-yogo-adaptatsiyi-v-ukrayini/ (in Ukrainian)

Zhyrko, S. O. Problemy rozvytku maloho ta serednoho pidpryyemnytstva v Ukrayini [Problems of development of small and average business in Ukraine]. Retrieved from: http://www.kbuapa.kharkov.ua/e-book/db/2007-1-2/ doc/2/25.pdf (in Ukrainian)

Samotoyenkova, O. V. (2005). Osoblyvosti rozvytku rynkovoyi infrastruktury v Ukrainy [Features of development of market infrastructure in Ukraine]. Visnyk sotsialno-ekonomichnykh doslidzhen, 19, 278-282. (in Ukrainian)

Samotoyenkova, O. V. (2009). Statystyka rynku tovariv i posluh : navch. posibnyk [Statistics of commodity market and services: tutorial]. Odessa: ODEU. (in Ukrainian)

Zhalila, Ya. A. (2016). Malyy i seredniy biznes u poshukakh mistsya v stratehiyi ekonomichnoho zrostannya $\mathrm{v}$ Ukrainy [Small and medium business in search of the place in the strategy of economic growth in Ukraine]. Zb. nauk. stat.: Kyiv: Alterpres. (in Ukrainian)

Derzhavna sluzhba statystyky Ukrainy [State Statistics Service of Ukraine]. Retrieved from: http://www.ukrstat.gov.ua (in Ukrainian)

Klochko, Yu. O., Hryn N. V. (2016). Spryyannya malomu pidpryyemnytstvu: stratehiya diy [Assistance to small business: the strategy of actions]. Male pidpryyemnytstvo i menedzhment $v$ Ukrayini, 22-28. (in Ukrainian)

Klochko, Yu.O. (2017). Malyy ta seredniy biznes v Ukrayini: startovi mozhlyvosti, nynishni realiyi, stsenariyi na maybutnye [Small and medium business in Ukraine: starting opportunities, present realities, scenarios on the future]. Materialy vseukrayinskoyi konferentsiyi «Baryery ta mozhlyvosti maloho ta serednoho biznesu $v$ Ukrayini $\gg$. (in Ukrainian)

Honey, G. A. (2009). Short Guide to Reputation Risk. Farnham: Gower Publishing.

Strategy That Works - Harvard Business Review Press. Retrieved from: http://www.pwc.com/ua/uk/survey/ 2016/strategy-that-works.html

Frank J. Fabozzi (2002). The Handbook of Financial instruments: Handbook - Hoboken, New Jersey: John Wiley \& Sons Inc.

Michael E. Porter (2008). The Five Competitive Forces that Shape Strategy. Harvard Business Review, January. 